\title{
Economics of Out-planting of Important Agroforestry Species with Different Organic Inputs in South-eastern Rajasthan
}

\author{
Raju Jatav, S. B. S. Pandey*, Priyanka Solanki, Manju Attri and Bhupendra Singh \\ Department of Silviculture and Agroforestry, College of Horticulture \& Forestry, \\ Jhalrapatan, Jhalawar (Rajasthan), India \\ *Corresponding author
}

\section{Keywords}

Agroforestry,

Organic inputs,

Dalbergia sissoo,

Moringa oleifera,

Cost of cultivation

Article Info

Accepted:

20 October 2020

Available Online:

10 November 2020

\section{A B S T R A C T}

A field experiment was conducted to study the out- planting performance of Dalbergia sissoo Roxb. and Moringa oleifera Lam. plant at Harbal Garden, College of Horticulture and Forestry, Jhalawar (Rajasthan) from July, 2019 to March, 2020. The out planting experimental design was randomized block design (RBD) with three replication and at $5 \mathrm{x}$ $5 \mathrm{~m}(\mathrm{R} \times \mathrm{P})$ spacing with ten treatments for both the species separately. Doses of organic inputs (sand, FYM and/or vermicompost) were given in different quaninty as well as at different time. In out planting of Dalbergia sissoo, However, treatment $\mathrm{T}_{8}$ being costlier shown highly significant growth on many growth parameters and then treatment $T_{7}$. In Moringa oleifera out planting significantly highest growth parameters were recorded in treatment $T_{7}$ and then $T_{9}$ while statically significant minimum value was recorded in treatment $\mathrm{T}_{0}$. The economics of cultivation of shisam (Dalbergia sissoo) observed during the experiment and whole year on per plant basis that highest cost on out planting found in treatment $\mathrm{T}_{9}$ and had a value Rs 97 \& Rs 109.17 respectively and Rs. 43,666.67 per hectare and a minimum cost of out planting was recorded in treatment $\mathrm{T}_{0}$ [soil: control] which has value Rs 45.00 from initial to 240 DAP per plant and Rs. 57.17 in whole year while Rs 22,866.67 cost in one hectare area in the first year.

\section{Introduction}

Agroforestry as a land-use option potentially increases livelihood security through simultaneous production of food, fodder, firewood etc. and reduces vulnerability to climate and environmental change (Pandey, 2007; Tiwari et al., 2017). Concurrently, the agroforestry moderates micro-climate (reduction of wind speed, stabilization of daily mean temperature, modification of solar radiation, increase of air humidity and decrease of evaporation) and mitigates land degradation through the means of controlling water erosion, soil erosion, reclaiming marginalized land and increasing irrigation and agricultural productivity (Jerneck and Olsson, 2013; Oyebamiji et al., 2013). With their multi-layered vegetation structures, agroforestry plantations serve as an important habitat for wild flora and fauna. Generally, plantation is a large group of plants and especially trees under cultivation. A 
plantation is a large piece of land, especially in a tropical country, where crops such as rubber, coffee, tea, etc. are grown.

India having the vast potential of organic sources can effectively utilize this to sustain yield, improve soil aeration, permeability, aggregation, water and nutrient holding capacity, biological properties of soil and soil health.

Dalbergia sissoo Roxb. is one of the tropical timber tree species with multiple uses such as fuel wood, fodder, pulp, shade, shelter and Nfixing ability (Sharma et al., 2007). It is widely used in agroforestry and afforestation programmes in Indian subcontinent (Chander et al., 1998 and Huda et al., 2007). The tree is a strong light- demander right from the seedling stage. Being a pioneer tree species, requires full overhead light for successful regeneration and establishment. It has light crown and reproduces by seeds and suckers. Trunks are often crooked when grown in the open. Various compounds obtained from Shisham such as isoflavone, biochanin is a potent chemotherapeutic cancer preventive agent, estrogenic activity from the fresh flowers of $D$. sissoo.

Moringa is a suitable tree for agro-forestry system due to its deciduous nature erects growth habit, light foliage and strong coppicing power. It is drought resistant and can be grown in a wide variety of poor soils, even barren land, with soil $\mathrm{pH}$ between 4.5 and 9.0.

Moringa oleifera Lam. can be grown by seeds or cuttings and seeds had better results than using the cuttings. Seeds are planted $2 \mathrm{~cm}$ deep and germinate within 1-2 weeks (Kiragu et al., 2015) in any tropical and subtropical regions of the world with a temperature around $25-35^{\circ} \mathrm{C}$. It requires sandy or loamy soil with a slightly acidic to slightly alkaline
$\mathrm{pH}$ and a net rainfall of 250-3000 mm (Thurber and Fahey, 2010) but high rainfall in black cotton soil is not favorable for its cultivation. Germination rates are usually very good, as found out in India, but survival can drop to $0 \%$ after two weeks.

India is the largest producer of drumstick globally and Andhra Pradesh is the largest producing state of India followed by Karnataka and Tamil Nadu in both area and production (Barela et al., 2019). Various parts of Moringa plant such as the leaves, roots, seed, bark, fruit, flower and immature pods are used for food, certain nutritional and/or medicinal propose (Rebecca et al., 2006); (Muhl, 2009), water treatment and also an important source of income for local and national economies (Kiragu et al., 2015), for fodder and its gum is used in textile industries (Paliwal \& Sharma, 2011).

\section{Materials and Methods}

The present research was conducted at the Herbal Garden, College of Horticulture and Forestry, Jhalrapatan city, Jhalawar (Rajasthan). Geographically, Jhalawar district falls in zone-V i.e. humid south-eastern plains. The district is bounded on the northwest by Kota district, on the northeast by Baran district, on the east by Guna district of Madhya Pradesh state, on the south by Rajgarh and Shajapur districts of Madhya Pradesh state and on the west by Ratlam, Mandsaur and Nimach districts of Madhya Pradesh state. The district occupies an area of $6928 \mathrm{~km}^{2}$ and district lies in the south eastern corner of Rajasthan between Latitude $23^{\circ} 45^{\prime} 20^{\prime \prime}$ to $24^{\circ} 52^{\prime} 17^{\prime \prime}$ \& Longitude $75^{\circ} 27^{\prime} 35^{\prime \prime}$ to $76^{\circ} 56^{\prime} 48^{\prime \prime}$. The district head quarter Jhalawar is situated on the national highway no. 12 about $85 \mathrm{Km}$ from Kota. Total area under forest is about 127328 ha and cultivated land is 336562 ha. Average annual rainfall is $919.6 \mathrm{~mm}$. Agriculture and 
forest lands occupy 73.5 percent area in the district.

Following doses of Sand, FYM and Vermicompost were given to each treatment with three replication are given in the Table 1 .

The initial expenditure in terms of rupees per plant and per treatment was worked out on the basis of cost of cultivation of each treatment per plant and per hectare.

\section{Results and Discussion}

\section{Shisam (Dalbergia sissoo)}

The economics of cultivation of shisam (Dalbergia sissoo) is presented in Table 2 and graphically in Figure 1. In whole period of the experiment, the highest cost on out planting was observed in treatment $\mathrm{T}_{9}$ [Vermicompost ( $2 \mathrm{~kg}$ at basal application $+1 \mathrm{~kg}$ in October, $2019+1 \mathrm{~kg}$ in January, 2020) + FYM (2 kg at basal application $+1 \mathrm{~kg}$ in October, $2019+1$ $\mathrm{kg}$ in January, 2020)] and had a value Rs 1160, Rs 1310 in whole year and Rs 43,666.67 cost/ha. Followed by $\mathrm{T}_{8}, \mathrm{~T}_{7}, \mathrm{~T}_{6}, \mathrm{~T}_{5}$ and minimum cost of out planting was recorded in treatment $T_{0}$ [soil: control] which has value Rs 536 from initial to 240 DAP and
Rs 686 in whole year while Rs. 22,866.67 cost in one hectare area in first year. Similar trends was observed by Dahiya (2002) in Ber cultivation in Rohtak district of Haryana; Meena et al., (2018) in Psidium guava. Barela et al., (2019) in Moringa oleifera L.; Nasreen et al., (2013) in Mandarin (Citrus reticulata) with the combined application of $\mathrm{N}, \mathrm{P}, \mathrm{K}$ and $\mathrm{Mg}$ along with organic manure; Bakshi et al., (2018) recorded in Kinnow Mandarin cultivation using inorganic and organic inputs along with bio fertilizers.

\section{Saijana (Moringa oleifera)}

Where as in case of Saijana (Moringa oleifera), it is presented in Table 3 and graphically in Figure 2. In whole period of the experiment, the highest cost on out planting was observed in treatment $\mathrm{T}_{9}$ [Vermicompost ( $2 \mathrm{~kg}$ at basal application $+1 \mathrm{~kg}$ in October, $2019+1 \mathrm{~kg}$ in January, 2020) + FYM (2 kg at basal application $+1 \mathrm{~kg}$ in October, $2019+1$ $\mathrm{kg}$ in January, 2020)] and had value Rs 1184, Rs 1334 in whole year and Rs 44,466.67 cost/ha. followed by $\mathrm{T}_{8}, \mathrm{~T}_{7}, \mathrm{~T}_{6}, \mathrm{~T}_{5}$ and minimum cost of out planting was recorded in treatment $\mathrm{T}_{0}$ [soil: control] which has value Rs 560 from initial to 240 DAP and Rs 710 in whole year while Rs 23666.67.

Table.1 Treatment name, organic inputs and various doses of inputs at different period

\begin{tabular}{|c|l|}
\hline $\begin{array}{c}\text { Treatment } \\
\text { Name }\end{array}$ & \multicolumn{1}{c|}{$\begin{array}{c}\text { Treatment inputs, Quantity (Kg. per plant) } \\
\text { (Dose=Basal dose + Oct-19+ Jan-20) }\end{array}$} \\
\hline $\mathbf{T}_{\mathbf{0}}$ & Soil (Control) \\
\hline $\mathbf{T}_{\mathbf{1}}$ & Sand [1 kg as basal application only] \\
\hline $\mathbf{T}_{\mathbf{2}}$ & FYM [2 kg as basal application only] \\
\hline $\mathbf{T}_{\mathbf{3}}$ & $1 \mathrm{~kg}$ as basal application only \\
\hline $\mathbf{T}_{\mathbf{4}}$ & Sand : FYM [1 kg. sand + FYM $(1+1+1)]$ \\
\hline $\mathbf{T}_{\mathbf{5}}$ & Sand : FYM [1 kg. sand + FYM (2+1+1)] \\
\hline $\mathbf{T}_{\mathbf{6}}$ & Sand : Vermicompost [1 kg. sand + Vermicompost $(1+1+1)]$ \\
\hline $\mathbf{T}_{\mathbf{7}}$ & Sand : Vermicompost [1 kg. sand + Vermicompost $(2+1+1)]$ \\
\hline $\mathbf{T}_{\mathbf{8}}$ & Vermicompost + FYM [Vermicompost $(1+1+1)+$ FYM $(1+1+1)]$ \\
\hline $\mathbf{T}_{\mathbf{9}}$ & Vermicompost + FYM [Vermicompost $(2+1+1)+$ FYM $(2+1+1)]$ \\
\hline
\end{tabular}


Table.2 Influence of various growing media on economics of cultivation of Shisam (Dalbergia sissoo)

\begin{tabular}{|c|c|c|c|c|c|c|c|c|c|c|c|c|c|c|}
\hline \multirow{3}{*}{$\begin{array}{c}\text { Treatments } \\
\text { (Dose=Basal } \\
\text { dose + Oct-19 } \\
\text { + Jan-20) }\end{array}$} & \multicolumn{10}{|c|}{ Dalbergia sissoo - Economics of cultivation (Rs) during the experiment } & \multicolumn{4}{|c|}{ Cost (Rs) in whole year } \\
\hline & \multirow[t]{2}{*}{$\begin{array}{c}\text { Pits } \\
\text { digging }\end{array}$} & \multicolumn{3}{|c|}{$\begin{array}{c}\text { Cost of growing media } \\
\text { (Rs) }\end{array}$} & \multirow{2}{*}{$\begin{array}{c}\text { Seedling } \\
\text { (including } \\
\text { transport) } \\
\text { cost (Rs) }\end{array}$} & \multirow[t]{2}{*}{$\begin{array}{l}\text { Stacking } \\
\text { cost (Rs) }\end{array}$} & \multicolumn{2}{|c|}{ Labour cost (Rs) } & \multirow{2}{*}{$\begin{array}{l}\text { Total } \\
\text { cost } \\
(\mathbf{R s})\end{array}$} & \multirow{2}{*}{$\begin{array}{c}\text { Cost } \\
\text { per } \\
\text { plant } \\
(\text { Rs })\end{array}$} & \multirow{2}{*}{$\begin{array}{c}\text { Cost in } \\
\text { remaining } \\
\text { months of } \\
\text { year }\end{array}$} & \multirow{2}{*}{$\begin{array}{c}\text { Total } \\
\text { cost } \\
(\mathbf{R s})\end{array}$} & \multirow{2}{*}{$\begin{array}{c}\text { Cost } \\
\text { per } \\
\text { plant } \\
(\mathbf{R s})\end{array}$} & \multirow{2}{*}{$\begin{array}{c}\text { Total cost } \\
\text { (Rs) per } \\
\text { ha }\end{array}$} \\
\hline & & Sand & FYM & $\begin{array}{l}\text { Vermi- } \\
\text { compost }\end{array}$ & & & Irrigation & Weeding & & & & & & \\
\hline $\mathbf{T}_{\mathbf{0}}$ & 120 & 0 & 0 & 0 & 156 & 60 & 100 & 100 & 536 & 45 & 150 & 686 & 57.17 & 22866.67 \\
\hline $\mathbf{T}_{1}$ & 120 & 48 & 0 & 0 & 156 & 60 & 100 & 100 & 584 & 49 & 150 & 734 & 61.17 & 24466.67 \\
\hline $\mathbf{T}_{2}$ & 120 & 0 & 120 & 0 & 156 & 60 & 100 & 100 & 656 & 55 & 150 & 806 & 67.17 & 26866.67 \\
\hline $\mathbf{T}_{\mathbf{3}}$ & 120 & 0 & 0 & 96 & 156 & 60 & 100 & 100 & 632 & 53 & 150 & 782 & 65.17 & 26066.67 \\
\hline $\mathbf{T}_{4}$ & 120 & 48 & 180 & 0 & 156 & 60 & 100 & 100 & 764 & 64 & 150 & 914 & 76.17 & 30466.67 \\
\hline $\mathbf{T}_{5}$ & 120 & 48 & 240 & 0 & 156 & 60 & 100 & 100 & 824 & 69 & 150 & 974 & 81.17 & 32466.67 \\
\hline$T_{6}$ & 120 & 48 & 0 & 288 & 156 & 60 & 100 & 100 & 872 & 73 & 150 & 1022 & 85.17 & 34066.67 \\
\hline $\mathbf{T}_{7}$ & 120 & 48 & 0 & 384 & 156 & 60 & 100 & 100 & 968 & 81 & 150 & 1118 & 93.17 & 37266.67 \\
\hline $\mathbf{T}_{8}$ & 120 & 0 & 288 & 180 & 156 & 60 & 100 & 100 & 1004 & 84 & 150 & 1154 & 96.17 & 38466.67 \\
\hline $\mathbf{T}_{9}$ & 120 & 0 & 384 & 240 & 156 & 60 & 100 & 100 & 1160 & 97 & 150 & 1310 & 109.17 & 43666.67 \\
\hline Total (Rs) & 1200 & 240 & 1212 & 1188 & 1560 & 600 & 1000 & 1000 & 8000 & & 1500 & 9500 & & \\
\hline
\end{tabular}

*Note:

1. $\quad$ Tractor + pit digging cost $=$ Rs 10 per pit

2. $\quad$ Cost of Sand $=$ Rs 4 per kg

3. Cost of FYM = Rs 5 per kg

4. $\quad$ Cost of Vermicompost $=$ Rs 8 per kg

5. Seedlings (including transport cost) purchase cost $=$ Rs 13 per plant

6. Bamboo sticks for stacking $=$ Rs 5 per stick

7. Labour cost $=$ Rs 250 per labour $/$ day 
Table.3 Influence of various growing media on economics of cultivation of Saijana (Moringa oleigera)

\begin{tabular}{|c|c|c|c|c|c|c|c|c|c|c|c|c|c|c|}
\hline \multirow[t]{3}{*}{ Treatments } & \multicolumn{10}{|c|}{ Moringa oleifera - Economics of cultivation (Rs) during the experiment } & \multicolumn{4}{|c|}{ Cost (Rs) in whole year } \\
\hline & \multirow[t]{2}{*}{$\begin{array}{c}\text { Pits } \\
\text { digging }\end{array}$} & \multicolumn{3}{|c|}{$\begin{array}{c}\text { Cost of growing media } \\
\text { (Rs) }\end{array}$} & \multirow{2}{*}{$\begin{array}{l}\text { Seedling } \\
\text { (including } \\
\text { transport) } \\
\text { cost (Rs) }\end{array}$} & \multirow[t]{2}{*}{$\begin{array}{l}\text { Stacking } \\
\text { cost }(\mathbf{R s})\end{array}$} & \multicolumn{2}{|c|}{ Labour cost (Rs) } & \multirow{2}{*}{$\begin{array}{l}\text { Total } \\
\text { cost } \\
(\mathrm{Rs})\end{array}$} & \multirow{2}{*}{$\begin{array}{l}\text { Cost } \\
\text { per } \\
\text { plant } \\
(\text { Rs })\end{array}$} & \multirow{2}{*}{$\begin{array}{c}\text { Cost in } \\
\text { remaining } \\
\text { months of } \\
\text { year } \\
\text { Weeding } \\
\& \\
\text { Irrigation }\end{array}$} & \multirow{2}{*}{$\begin{array}{l}\text { Total } \\
\text { cost } \\
(\text { Rs })\end{array}$} & \multirow{2}{*}{$\begin{array}{l}\text { Cost } \\
\text { per } \\
\text { plant } \\
(\text { Rs })\end{array}$} & \multirow{2}{*}{$\begin{array}{c}\text { Total } \\
\text { cost } \\
\text { (Rs) per } \\
\text { ha }\end{array}$} \\
\hline & & Sand & FYM & $\begin{array}{l}\text { Vermi- } \\
\text { compost }\end{array}$ & & & Irrigation & Weeding & & & & & & \\
\hline $\mathbf{T}_{\mathbf{0}}$ & 120 & 0 & 0 & 0 & 180 & 60 & 100 & 100 & 560 & 47 & 150 & 710 & 59.17 & 23666.7 \\
\hline $\mathbf{T}_{1}$ & 120 & 48 & 0 & 0 & 180 & 60 & 100 & 100 & 608 & 51 & 150 & 758 & 63.17 & 25266.7 \\
\hline $\mathbf{T}_{2}$ & 120 & 0 & 120 & 0 & 180 & 60 & 100 & 100 & 680 & 57 & 150 & 830 & 69.17 & 27666.7 \\
\hline $\mathbf{T}_{\mathbf{3}}$ & 120 & 0 & 0 & 96 & 180 & 60 & 100 & 100 & 656 & 55 & 150 & 806 & 67.17 & 26866.7 \\
\hline $\mathbf{T}_{4}$ & 120 & 48 & 180 & 0 & 180 & 60 & 100 & 100 & 788 & 66 & 150 & 938 & 78.17 & 31266.7 \\
\hline $\mathbf{T}_{5}$ & 120 & 48 & 240 & 0 & 180 & 60 & 100 & 100 & 848 & 71 & 150 & 998 & 83.17 & 33266.7 \\
\hline $\mathbf{T}_{6}$ & 120 & 48 & 0 & 288 & 180 & 60 & 100 & 100 & 896 & 75 & 150 & 1046 & 87.17 & 34866.7 \\
\hline $\mathbf{T}_{7}$ & 120 & 48 & 0 & 384 & 180 & 60 & 100 & 100 & 992 & 83 & 150 & 1142 & 95.17 & 38066.7 \\
\hline $\mathbf{T}_{8}$ & 120 & 0 & 288 & 180 & 180 & 60 & 100 & 100 & 1028 & 86 & 150 & 1178 & 98.17 & 39266.7 \\
\hline $\mathbf{T}_{9}$ & 120 & 0 & 384 & 240 & 180 & 60 & 100 & 100 & 1184 & 99 & 150 & 1334 & 111.2 & 44466.7 \\
\hline Total (Rs) & 1200 & 240 & 1212 & 1188 & 1800 & 600 & 1000 & 1000 & 8240 & & 1500 & 9740 & & \\
\hline
\end{tabular}

*Note:

1. Tractor + pit digging cost $=$ Rs 10 per pit

2. Cost of Sand $=$ Rs 4 per kg

3. Cost of FYM = Rs 5 per kg

4. Cost of Vermicompost $=$ Rs 8 per $\mathrm{kg}$

5. Seedlings (including transport cost) purchase cost $=$ Rs 15 per plant

6. Bamboo sticks for stacking $=$ Rs 5 per stick

7. Labour cost $=$ Rs 250 per labour/day 
Fig.1 Influence of various growing media on economics of cultivation of Shisam (Dalbergia sissoo)

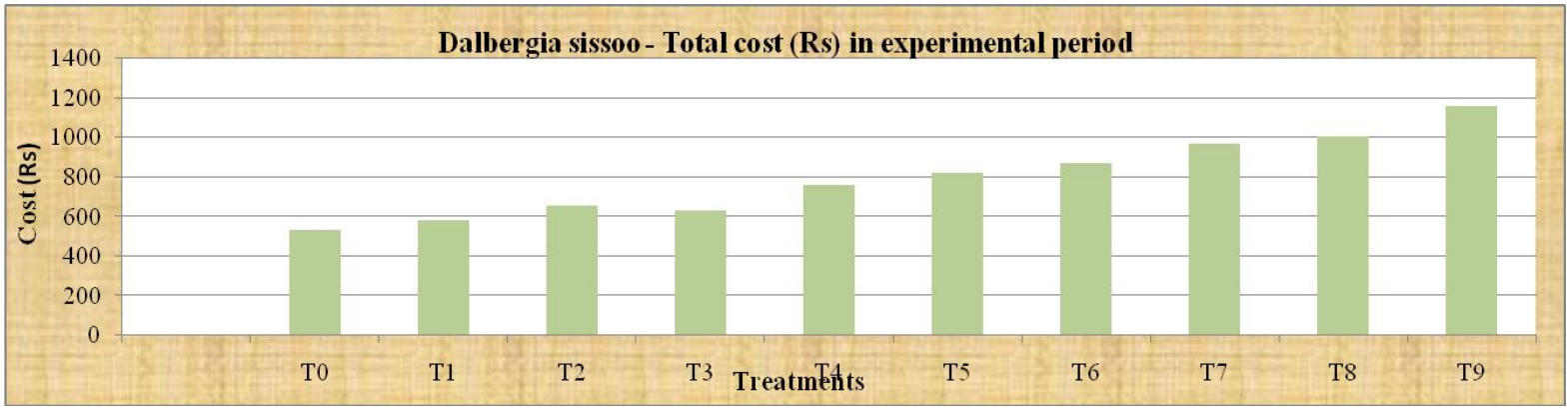

Fig.2 Influence of various growing media on economics of cultivation of Saijana (Moringa oleigera)

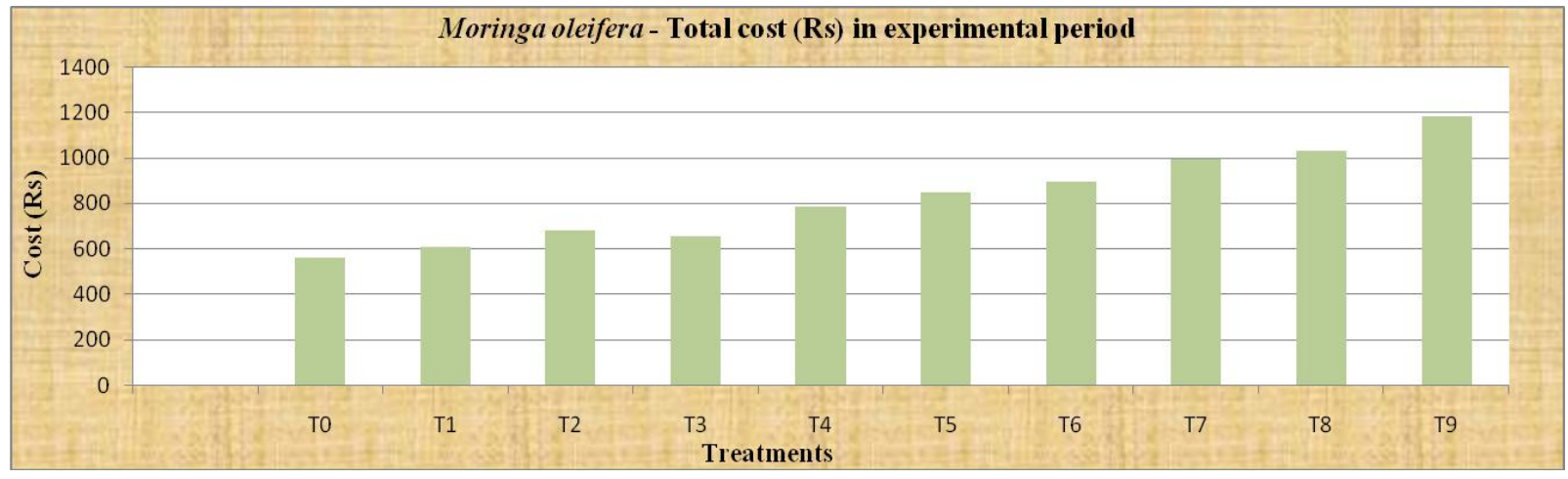

Similar trends was observed by Barela et al., (2019) in Moringa oleifera L.; Nasreen et al., (2013) in Mandarin (Citrus reticulata) with the combined application of $\mathrm{N}, \mathrm{P}, \mathrm{K}$ and $\mathrm{Mg}$ along with organic manure; Bakshi et al., (2018) recorded in Kinnow Mandarin cultivation using inorganic and organic inputs along with bio fertilizers; Dahiya (2002) in Ber cultivation in Rohtak district of Haryana; Meena et al., (2018) in Psidium guava.

\section{References}

Bakshi, M., Wali, V.K., Sharma, A. and Raina, V. (2018).Economics Evaluation of Kinnow Mandain cultivation using Inorganic and organic nutrient sources along with Biofertilizers. International Journal of Current Microbiology and Applied
Sciences; 7(8): 130-138.

Barela, B., Kureel, M.K., Mandloi, D.S. and Kumar, (2019). Effect of different concentrations of organic manures with Azotobacter on seed germination and early seedling growth of Moringa oleifera L. Journal of Pharmacognosy and Phytochemistry; 8(6): 610-613.

Chander, K., Goyal, S., Nandal, D.P. and Kapoor, K.K. (1998). Soil organic matter, microbial biomass and enzyme activities in tropical Agroforestry system. Biology and Fertility of Soil, 27: $168-172$.

Dahiya, P. (2002). Cost-benefit analysis of Ber cultivation in Rohtak district of Haryana. Indian Journal of Agricultural Marketing, 16(2): 48-52.

Huda, S.M.S., Sujauddin, M., Shafinat, S. and Uddin, M.S. (2007). Effect of 
phosphorus and potassium addition on growth and nodulation of Dalbergia sissoo in the nursery. Journal of Forestry Research, 18: 279-282.

Jerneck, A. and Olsson, L. (2013). More than trees! Understanding the agroforestry adoption gap in subsistence agriculture: Insights from narrative walks in Kenya. Journal of Rural Studies, 32: 114-125.

Kiragu, J.W., Mathenge, P. and Kireger, E. (2015). Growth Performance of Moringa oleifera Planting Materials Derived from Cuttings and Seeds. International Journal of Plant Science and Ecology, 4: 142-148.

Meena, C., Meena, R.R., Meena, K.C., Meena, B.L., and Meena, K.R. (2018). Doubling the farmer income through Guava (Psidium guajava) cultivation. International Journal of Science, Environment and Technology; 7(3): 905-909.

Muhl, Q.E. (2009). Seed germination, tree growth and flowering responses of Moringa oleifera lam. (horseradish tree) to temperature (Doctoral dissertation, University of Pretoria).

Nasreen, S., Ahmed, R., Ullah, M.A. and Hoque M.A. (2013). Effect of N, P, K and $\mathrm{Mg}$ application on yield and fruit quality of Mandarin (Citrus reticulata). Bangladesh Journal of Agricultural Research; 38(3): 425-433.

Oyebamiji, N.A., Adedire, M.O. Aduradola, A.M. and Agboola, D.A. (2013). Potential benefits of agroforestry practices on livelihood and environment of farmers in Odeda Local Government, Area of Ogun State, Nigeria. International Journal of Science and Nature, 4(4): 603-607.

Paliwal, R. and Sharma, V. (2011). A review on horse radish tree (Moringa oleifera): A multipurpose tree with high economic and commercial importance. Asian journal of Biotechnology, 3: 317-328.

Pandey, D.N. (2007). Multifunctional agroforestry systems in India. Current Science, 92(4): 455-463.

Rebecca, H.S.U., Sharon, M., Arbainsyah, A. and Lucienne, D. (2006). Moringa oleifera: Medicinal and SocioEconomic Uses. International Course on Economic Botany. National Herbarium Leiden, Netherlands, 2-6.

Sharma, R., Kumar, S., Thakur, K.S. and Kumar, S. (2007). Estimates of genetic parameters from an open pollinated progeny test of Shisham (Dalbergia sissoo Roxb.). Indian Journal of Forestry, 30(3): 273-278.

Thurber, M.D. and Fahey, J.W. (2010). Adoption of Moringa oleifera to combat under-nutrition viewed through the lens of the diffusion of innovations theory, Ecol. Food Sci. Nutr. 48: 1-13.

Tiwari, P., Kumar, R., Thakur, L. and Salve, A. (2017). Agroforestry for sustainable rural livelihood: A review. International Journal of Pure and Applied Bioscience, 5(1): 299-309.

\section{How to cite this article:}

Raju Jatav, S. B. S. Pandey, Priyanka Solanki, Manju Attri and Bhupendra Singh. 2020. Economics of Out- planting of Important Agroforestry Species with Different Organic Inputs in South-eastern Rajasthan. Int.J.Curr.Microbiol.App.Sci. 9(11): 2165-2171. doi: https://doi.org/10.20546/ijcmas.2020.911.257 